Riordan, M. M., P. M. Lukacs, K. P. Huyvaert, and V. J. Dreitz. 2015. Sex ratios of Mountain Plovers from egg production to fledging. Avian Conservation and Ecology 10(2):3. http://dx.doi.org/10.5751/ACE-00772-100203

Copyright (C) 2015 by the author(s). Published here under license by the Resilience Alliance.

Research Paper

\title{
Sex ratios of Mountain Plovers from egg production to fledging
}

\author{
Margaret M. Riordan ${ }^{1}$, Paul M. Lukacs ${ }^{1}$, Kathryn P. Huyvaert ${ }^{2}$ and Victoria J. Dreitz ${ }^{1}$
}

${ }^{1}$ University of Montana, ${ }^{2}$ Colorado State University

\begin{abstract}
Skewed sex ratios can have negative implications for population growth if they do not match a species' life history. A skewed tertiary sex ratio has been detected in a population of Mountain Plover (Charadrius montanus), a grassland shorebird experiencing population declines. To study the cause of the observed male skew, we examined three early life stages between egg and fledgling in eastern Colorado from 2010 to 2012. This allows us to distinguish between egg production and chick survival as an explanation for the observed skew. We examined the primary sex ratio in eggs produced and the secondary sex ratio in hatched chicks to see if the sex ratio bias occurs before hatching. We also determined the sex ratio at fledging to reveal sex-specific mortality of nestlings. The primary sex ratio was $1.01( \pm 0.01)$ males per female. The secondary sex ratio consisted of $1.10( \pm 0.02)$ males per female. The probability of a chick surviving to fledging differed between males $(0.55 \pm 0.13)$ and females $(0.47 \pm 0.15)$, but the precision of these survival estimates was low. Sex ratios in early life stages of the Mountain Plover do not explain the skewed sex ratio observed in adults in this breeding population.
\end{abstract}

\section{Sex-ratios de la production d'oeufs à l'envol chez le Pluvier montagnard}

RÉSUMÉ. Des sex-ratios déséquilibrées peuvent avoir des effets négatifs sur la croissance d'une population si elles sont trop éloignées de la biodémographie naturelle de l'espèce. Une sex-ratio tertiaire déséquilibrée a été détectée chez une population de Pluvier montagnard (Charadrius montanus), un oiseau de rivage qui se reproduit dans les prairies et dont les populations sont en baisse. Dans le but d'étudier la cause du déséquilibre observé favorisant les mâles, nous avons examiné trois stades précoces des oeufs à l'envol, dans l'est du Colorado de 2010 à 2012. Cet examen nous a permis d'établir si la production d'oeufs ou la survie des jeunes pouvait expliquer la sex-ratio déséquilibrée. Nous avons examiné la sex-ratio primaire des oeufs et la sex-ratio secondaire des poussins éclos afin de déterminer si le déséquilibre de la sex-ratio était présent avant l'éclosion. Nous avons aussi déterminé la sex-ratio des jeunes à l'envol pour obtenir la mortalité spécifique au sexe des oisillons. La sex-ratio primaire s'élevait à 1,01 $( \pm 0,01)$ mâle par femelle. La sex-ratio secondaire était de $1,10( \pm 0,02)$ mâle par femelle. La probabilité qu'un oisillon survive jusqu'à l'envol était différente entre les mâles $(0,55 \pm 0,13)$ et les femelles $(0,47 \pm 0,15)$, mais la précision de ces estimations de survie était faible. La sex-ratio observée aux stades précoces n'explique pas le déséquilibre de la sex-ratio chez les adultes de cette population nicheuse de Pluvier montagnard.

Key Words: Charadrius montanus; chick survival; Mountain Plover; primary sex ratio; secondary sex ratio

\section{INTRODUCTION}

Sex ratios are a key aspect of a species' natural history and are particularly important in understanding behavior, social structure, and breeding system dynamics (Székely et al. 2006, Kosztolányi et al. 2011). As a result, understanding what drives skewed sex ratios, i.e., a sex ratio different from 1:1, can be important in predicting a species' future population growth, viability, and vulnerability to extinction (Hardy 2002, Donald 2007). Knowledge of the mechanisms contributing to a skewed sex ratio, and the life stage at which the skew arises, are necessary to determine if a skew is adaptive or is a negative consequence of survival differences.

Hypothesized mechanisms for skewed sex ratios among adults are numerous and typically species-specific. One hypothesis is that a species' breeding system, including the type of pair-bond and degree of parental care, may cause skewed sex ratios to arise (Reynolds and Székely 1997, Thomas et al. 2007). A higher proportion of males or females may be necessary to maximize fitness depending on the breeding system. For example, in a polyandrous system where males serve as the care provider, male parental care may limit recruitment of offspring; an adaptive sex ratio will be male-biased. This is observed in the polyandrous Kentish Plover (Charadrius alexandrinus; Kosztolányi et al. 2011). However, a skewed sex ratio may not be adaptive and a species may adjust its parental care strategy as a response to the proportion of males or females contributing to reproductive effort in the population (McNamara et al. 2000, Kokko and Jennions 2008, Kosztolányi et al. 2011). Additionally, skewed sex ratios can arise as a result of variation in environmental factors that contribute to differential mortality (e.g., Awkerman et al. 2006) or skewed production of one sex (Leshyk et al. 2012), possibly having negative consequences for population growth.

Finally, sex ratio is an important component when estimating extinction risk (Brook et al. 2000). This risk is thought to be higher for populations with a male skewed sex ratio than those with a female skewed sex ratio (Donald 2007) because females are typically the limiting sex in production of offspring. A maledominated sex ratio in a population can have negative 
consequences for several reasons. First, a skewed sex ratio may have arisen from a higher mortality rate among females and increased mortality in itself can lead to population declines. Second, density-dependent mechanisms can have negative effects with heavily skewed sex ratios. For example, in low density populations the probability of encountering an individual of the opposite sex can be greatly reduced. This could subsequently increase both the time and energy expended searching for a mate although the limited sex may encounter mates more easily than the majority sex. Populations near carrying capacity and with a surplus of males that are not contributing to reproductive output can lead to increased resource competition. Additionally, if females are the limiting sex in production of offspring, male skewed sex ratios have important implications for growth rates of populations through influences on reproductive potential.

The Mountain Plover (Charadrius montanus) is an upland shorebird that has a male skewed tertiary sex ratio, i.e., sex ratio of adults, on both their breeding (Dinsmore et al. 2002, Dinsmore and Knopf 2005, Dreitz 2009) and wintering grounds (Knopf and Wunder 2006). A tertiary skew ranging from 1.6 (Dreitz 2009) to 2.3 (V.J. Dreitz, unpublished data; 107 males, 47 females in eastern Colorado) males per female has been observed in nesting birds from one study area within their breeding range. The species' breeding strategy is defined as a rapid multiclutch system where at least two nests are laid: one for a male and one for a female caregiver to tend (Knopf and Wunder 2006). Uniparental care begins with incubation and continues through chick-rearing (Graul 1975). In practice, female Mountain Plovers may lay more than two nests; a male-biased sex ratio among caregivers would be advantageous in populations with this breeding strategy.

Mountain Plover populations have experienced significant population declines over the last several decades (Sauer et al. 2011, USFWS 2011), and these declines have been linked to some degree to variation in adult survival, chick survival, and nest success depending on the study population (Dinsmore et al. 2010). Dinsmore et al. (2010) suggested that survival from hatching to \%35 days may limit Mountain Plover population growth; Mountain Plover chick survival is lowest immediately after hatching and subsequently increases within $4 \mathrm{~d}$ posthatch (Lukacs et al. 2004). Daily survival rates of Mountain Plover chicks continue to increase with age until they approach adult survival rates (Knopf and Rupert 1996, Lukacs et al. 2004, Dinsmore and Knopf 2005), but may differ between males and females, an aspect that is unexplored.

Evaluating the sex ratio at each stage of the life history is key to understanding whether observed male-biased tertiary sex ratios are an adaptive trait related to the breeding system or if the skew could be contributing to population declines. Studying the early life stages is the first step in understanding when in the life cycle the skewed sex ratio arises. If the skewed sex ratio is nonadaptive and occurs in the early life stages, management efforts could be used to reduce mortality of birds of one sex. The objectives of this study were to: (1) evaluate the primary and secondary sex ratios in Mountain Plovers in eastern Colorado, (2) determine survival rates of male and female Mountain Plover chicks, and (3) evaluate potential factors that may influence survival from hatching to fledging.

\section{METHODS}

\section{Field methods}

Our study site is located on private lands in eastern Colorado near the town of Karval $\left(38^{\circ} 44^{\prime} \mathrm{N} 103^{\circ} 32^{\prime} \mathrm{W}\right)$ in Lincoln County. Data collection occurred from April to August each year from 2010 to 2012. The region is arid with large daily fluctuations in temperature. The area has a primarily flat topography and the vegetation is composed of a matrix of native shortgrass prairie (predominantly Bouteloua dactyloides and B. gracilis) and dryland agricultural fields. Shortgrass prairie may be grazed by black-tailed prairie dogs (Cynomys ludovicianus) or domestic livestock. Dryland agricultural fields are mostly wheat (Tricum aestivum) crops and fallow strips with variable amounts of crop stubble.

Sex of individual offspring was evaluated using DNA from tissue samples collected from eggs and monomorphic chicks, outlined below. Primary sex ratio was determined from DNA samples of eggs and chicks combined, whereas secondary sex ratio was determined using only chicks, a subset of the individuals used to calculate the primary sex ratio.

We located nests using transect surveys on suitable breeding habitat where landowners granted access. Nests were marked, e.g., natural markers and a GPS point, such that they could be relocated. Each egg within a nest was uniquely marked with nontoxic marker to identify hatching order. Egg volume was calculated with a similar equation used in previous studies on Mountain Plovers (Skrade and Dinsmore 2013) and Semipalmated Plovers (C. semipalmatus, Nol et al. 1997), as:

$$
V=0.4482 \times L \times B^{2}-0.269
$$

where $V=$ volume $\left(\mathrm{cm}^{3}\right), L=$ length $(\mathrm{cm})$ and $B=$ breadth (or width; $\mathrm{cm}$ ). Nests were monitored until eggs hatched or the nest failed.

Unhatched eggs were collected after observing that a nest failed to hatch, e.g., abandonment, tillage of the nest by agricultural practices, or flooding, or upon individual egg failure, e.g., siblings hatch and leave the nesting area with the adult. We placed individual eggs in plastic vials padded with cotton balls. In 2010 and 2011 , eggs were frozen at $-20^{\circ} \mathrm{C}$ and dissected at a later date. In 2012, eggs were immediately dissected. Egg fertility was determined by opening the egg and visually observing signs of embryonic development, i.e., the presence of blood vessels or an embryo. If the egg was fertile, small samples of tissue were collected and placed in $70 \%$ ethanol. The stage of development dictated the type of tissue collected. Brain tissue was extracted in mid- (embryo half way to full development, yolk sac decreased to approximately half original size) to late- (embryo very close to full development, small yolk sac remains) embryonic development. The entire embryo was the sample for eggs showing early development (embryo very small, the yolk sac formed the majority of egg contents) because brain tissue could not be identified in these cases.

Eggs were aged using a flotation method (Westerskov 1950, Dinsmore 2001) to facilitate sample collection near the hatching date. Once a chick hatched, a small blood sample $(<30 \mu \mathrm{L})$ was collected by jugular venipuncture. A 0.35 -g transmitter (Pip, Lotek 
Wireless, Inc., Canada, and Biotrack Ltd., UK, private vendor) was attached to chicks $(\sim 10 \mathrm{~g})$ at hatching once their plumage was fully dried. The mass of the transmitter met the established guidelines for transmitters of $<5 \%$ of body mass for small $(<50$ g) birds (Caccamise and Hedin 1985, Fair et al. 2010). Transmitters were attached using a modified design of Rappole and Tipton's (1991) leg harness attachment method (Dreitz et al. 2011) using a 40-mm leg loop harness. The battery life of the transmitters was $\sim 18$ days. We replaced transmitters at $\sim 16$ days of age to maintain monitoring until chicks were $\geq 30$ days of age. Chicks were monitored daily using radio telemetry on foot or from all-terrain vehicles. Observers maintained a distance of $>$ $250 \mathrm{~m}$ to limit disturbance to chicks. If we failed to locate a chick through ground-based methods, aerial surveys were done using a fixed-wing aircraft.

Mountain Plover chicks are precocial and leave the nest shortly after hatching (Graul 1975). If hatching is missed, finding the adult and its brood is difficult (Knopf and Rupert 1996). In an effort to avoid loss of broods, we attached a 1.8-g radio transmitter (BD-2, Holohil Systems, Ltd, Carp, ON, Canada; private vendor) to the incubating adult when a nest was $\leq 5$ days from hatching. Incubating adults were caught using a walk-in trap at the initial nest location and were banded with a United States Geological Survey (USGS) aluminum leg band. Transmitters on adults were placed between mantle feathers and attached using epoxy (Dinsmore and Knopf 2005, Dreitz et al. 2005, Dreitz 2009, 2010). Feathers were collected from all adult Mountain Plovers for molecular sexing analysis. All DNA samples, i.e., tissue from eggs, blood from chicks, and feathers from adults, were sent to Avian Biotech (Tallahassee, FL) for molecular sexing analyses.

\section{Statistical analysis}

Primary and secondary sex ratios were calculated using binary response data (male or female) collected over the three breeding seasons. We estimated probabilities of hatching for all eggs produced as well as for each sex separately. Estimates of the probability of hatching could include eggs of unknown sex.

We used logistic regression to evaluate the relationship that nestlevel and temporal covariates have with the probability an egg or chick was male in two separate analyses. Data were restricted to nests where the sexes of all the eggs within a nest were known. Nests that were depredated (partially or fully) or had unknown sex for $\geq 1$ individual, i.e., we were unable to collect a DNA sample in the field, or the sample yielded no result from the lab, were not included in these analyses. Generalized linear mixed models (GLMMs; Hosmer and Lemeshow 2000, Krackow and Tkadlec 2001, Székely et al. 2004) were fitted with a logit link function and a binomial distribution and were implemented in program $\mathrm{R}$ (version 2.15.2; R Core Team 2013). The sex of the individual (egg or chick) was the response variable and the individual's nest was included as a random effect. Explanatory variables included year, sex of tending adult, clutch size, and hatch day. Models were ranked using Akaike's Information Criterion adjusted for small sample size ( AIC $_{c}$; Burnham and Anderson 2002).

A multistate mark-recapture modeling approach (Nichols et al. 1992, Devineau et al. 2006, Rickenbach et al. 2011) was used to evaluate sex-specific apparent chick survival (Fig. 1). Two states were defined, "alive" and "dead." A third "unobserved" state was included to account for differences in detectability of chicks and represented both undetected, i.e., present and not detected, and unobservable, i.e., moved off the study area, transmitter malfunction, etc., individuals. Our model parameterization follows that of Dreitz (2010) and Devineau et al. (2014). $\Phi=$ fidelity was the probability the chick stayed in the study area during the chick period (i.e., no permanent emigration). Detection $(p)$, the probability of resighting chicks, was $<1.0$ due to transmitter malfunction, movement out of detection range, and predation, leading to a broken transmitter or transportation outside of the study area. Chicks were resighted as either live recaptures or dead recoveries. Sex-specific survival was estimated as $\Psi_{(A) \rightarrow(A)}$, the conditional probability of staying in an alive state (A) from time $t$ to $t+1$. This analysis was performed in Program MARK (White and Burnham 1999, White et al. 2006).

Fig. 1. Diagram illustrating the multistate mark-recapture model used to analyze Mountain Plover (Charadrius montanus) chick survival for males and females. Data were collected in eastern Colorado from 2010 to 2012. Multistate parameters include: transition $(\psi \mathrm{ij} ; \mathrm{i}=$ state at time $\mathrm{t}, \mathrm{j}=$ state at time $\mathrm{t}+1)$ probabilities between states and detection probabilities (p) while in states. Transition probabilities are based on the probability of a chick moving or remaining in a state on a daily basis. Three states are defined: alive (A), dead (D), and unobserved (U).

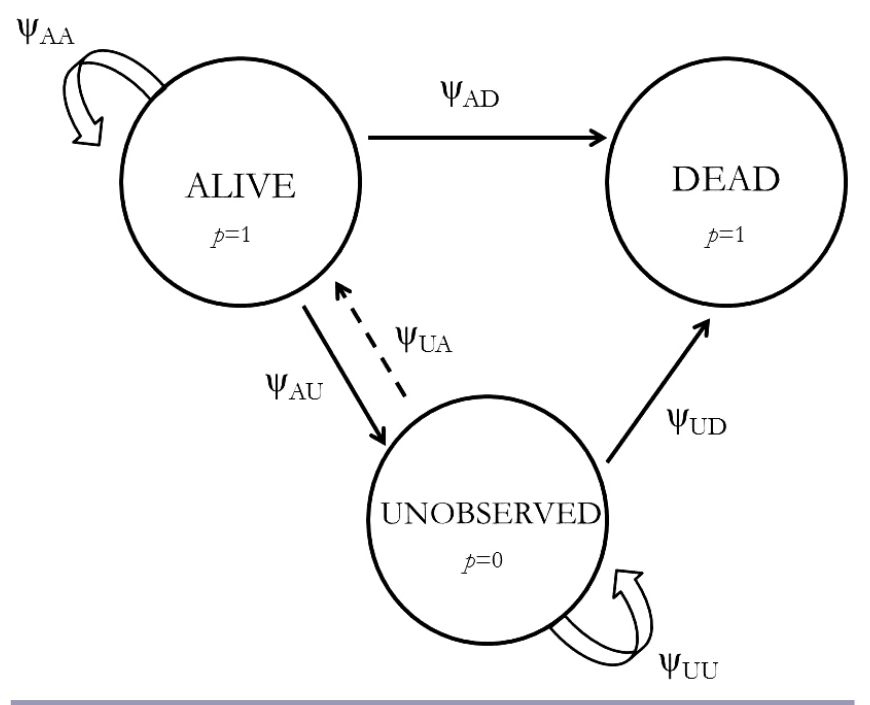

A set of candidate models was developed to evaluate male and female chick survival (Table 1). Sex of a chick was defined as female, male, or unknown. Fidelity, $\Phi$, was modeled as constant for the study because chicks are not likely to leave the study area given they are not capable of flight until $\geq 30$ days posthatch (Dreitz 2010). We kept $p$ constant for both live recaptures and dead recoveries. Radio telemetry was used to locate chicks. Factors such as habitat or observer are likely to influence live recaptures and dead recoveries similarly. We included models in which sex-specific $\Psi_{(A) \rightarrow(A)}$ between females and males differed except for one model in which sex-specific $\Psi_{(A) \rightarrow(A)}$ was equal (Table 1). We also considered chick mass, tarsus length, egg volume, sex of tending adult, year, hatching order, hatch day, and habitat type as potential factors influencing sex-specific $\Psi_{(A) \rightarrow(A)}$. Models were ranked based on Akaike's Information Criterion for small sample size (AIC $c$; Burnham and Anderson 2002). 
Table 1. Summary of model selection results for Mountain Plover (Charadrius montanus) sex-specific chick survival in eastern Colorado from the 2010 to 2012 breeding seasons. Multistate mark-recapture models were used to compare differences in survival between male and female chicks. Fidelity, $\Phi$, and detection probability of live recaptures and dead recoveries, $p$, were held constant for all models, thus omitted from the table. Models are presented in ascending order of Akaike's Information Criterion $\left(\mathrm{AIC}_{c}\right)$, with $\Delta \mathrm{AIC}_{c}$ indicating the difference between each model and the model with the lowest $\mathrm{AIC}_{c}$ value and the most $\mathrm{AIC}_{c}$ weight. Covariates used include hatch day (1 through 68; day 1 = May 9), adult sex (sex of tending adult), egg volume, tarsus (length of tarsal bone), mass (chick mass at hatching), year, and habitat type (grassland, grassland with prairie dogs, and agricultural fields). "+" denotes the parameter had an additive effect of two covariates.

\begin{tabular}{lcccc}
\hline \hline Model & & & & \\
Sex-Specific Survival $^{\dagger}$ & Parameters & AIC $_{c}$ & $\Delta \mathrm{AIC}_{c}$ & Weight \\
\hline Hatch Day + Adult Sex & 11 & 3933.36 & 0.00 & 0.39 \\
Hatch Day & 10 & 3933.75 & 0.39 & 0.32 \\
Hatch Day + Egg Volume & 11 & 3935.32 & 1.96 & 0.15 \\
Hatch Day + Habitat Type & 13 & 3935.38 & 2.02 & 0.14 \\
Tarsus + Mass & 11 & 3943.84 & 10.48 & 0.00 \\
Tarsus & 10 & 3943.87 & 10.51 & 0.00 \\
Tarsus + Egg Volume & 11 & 3945.63 & 12.27 & 0.00 \\
Mass & 10 & 3946.49 & 13.13 & 0.00 \\
Sex of Chick & 8 & 3946.94 & 13.57 & 0.00 \\
Mass + Egg Volume & 11 & 3947.66 & 14.30 & 0.00 \\
Female = Male & 9 & 3948.46 & 15.10 & 0.00 \\
Adult Sex & 10 & 3948.94 & 15.58 & 0.00 \\
Egg Volume & 10 & 3949.91 & 16.55 & 0.00 \\
Hatching Order & 10 & 3950.19 & 16.83 & 0.00 \\
Year & 11 & 3950.61 & 17.25 & 0.00 \\
Egg Volume + Hatching Order & 11 & 3951.73 & 18.37 & 0.00 \\
Habitat Type & 12 & 3952.34 & 18.98 & 0.00 \\
Habitat Type + Adult Sex & 13 & 3953.12 & 19.76 & 0.00 \\
\hline Turvival is estimated through & & & & \\
\hline
\end{tabular}

${ }^{\dagger}$ Survival is estimated through transition probabilities from the alive state to the dead state as described in Dreitz (2010) and Devineau et al. (2014). Models allowed survival to differ between males and females. * Survival was held equal between males and females.

\section{RESULTS}

\section{Primary and secondary sex ratios}

Fertility was evident in 346 eggs of which 121 eggs were males, 120 eggs were females, and 105 eggs were of unknown sex. The primary sex ratio was $1.01( \pm 0.01)$ males per female based on the 241 eggs of known sex, which is not significantly different from parity.

An egg, regardless of sex, had a $0.81 \pm 0.02$ (279 eggs hatched of 346 fertile eggs) probability of hatching. The sex of unhatched fertile eggs $(n=67)$ was determined as female for 17 eggs, male for 9 eggs, and 41 eggs were of unknown sex. Of the 279 hatched eggs, sex was determined for 215 eggs. The secondary sex ratio was $1.10( \pm 0.02)$ males per female based on the 215 known sex hatched eggs $($ females $=103$, males $=112)$. The overall probability that an egg or hatchling was a male $(0.51 \pm 0.03)$ was trivially higher than being a female $(0.49 \pm 0.03)$.
There was a high-level of model uncertainty in the suite of models we developed to understand the influence of year, sex of tending adult, clutch size, and hatch day on the primary and secondary sex ratios. Model selection yielded 3 top models within 2.0 $\Delta \mathrm{AIC}$ for the primary sex ratio and seven top models for the secondary ratio suggesting model selection uncertainty and no strong effects. To further support this, no coefficient in any model for either the primary or the secondary sex ratio analysis was considered significant, i.e., 95\% confidence intervals all included zero. Therefore, the estimates of the probability of an egg or a hatched egg was a male were not likely to be confounded with any of the covariates (year, sex of tending adult, clutch size, and hatch day) evaluated in this study.

\section{Chick survival}

A total of 234 individual chicks from 160 nests were monitored over the three breeding seasons. We identified sex for most individuals $(n=190)$, but field constraints precluded collection of field samples for molecular sexing of $19 \%$ of the chicks $(n=$ 44). Males and females were produced in nearly equal proportions over the course of the three years. A total of 31 chicks (13\%) were confirmed to survive $\geq 30$ days posthatch, of which 17 chicks were males.

Male Mountain Plover chicks survived with similar daily probabilities as females $(0.980 \pm 0.004$ and $0.975 \pm 0.004$, respectively). Projecting daily survival estimates over a course of 30 days yielded similar but higher survival probability in males $(0.548 \pm 0.13)$ than females $(0.472 \pm 0.15)$. Model selection results suggest that daily survival of male and female chicks was influenced most by hatch day and sex of the tending adult (Table $1)$. Individuals that hatched later in the breeding season showed lower survival probability ( $\beta=-0.03, \pm 0.01$; Fig. 2 ). Parameter estimates for covariates other than hatch day were not significant for any of the top ranked models (Table 1; adult sex $[\beta=0.18$, 95\% CI: -0.050 .42 ]; egg volume $[\beta=-0.21,95 \%$ CI: $-0.830 .40]$; grassland habitat $[\beta=-0.28,95 \% \mathrm{CI}$ : $-1.430 .86]$; prairie $\operatorname{dog}$ habitat $[\beta=-0.17, \mathrm{CI}:-1.341 .01]$; cropland habitat $[\beta=-0.76,95 \%$ CI: $-1.950 .44]$ ), suggesting no effect on survival.

Fig. 2. Survival probabilities of male and female Mountain Plover (Charadrius montanus) chicks based on data collected from 2010 to 2012 in eastern Colorado. Figure illustrates the relationship of survival probabilities between male and female chicks and day of hatching within the breeding season starting at day 1 (May 9) and continuing through day 68 (July 15).

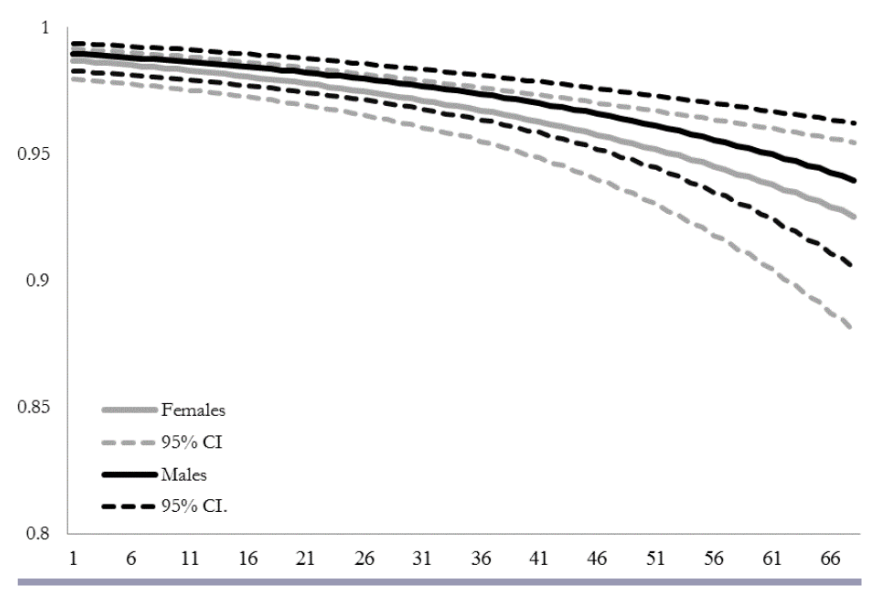




\section{DISCUSSION}

Our study provided little evidence that the male skewed sex ratio in a Mountain Plover breeding population is the result of an adaptive trait related to their breeding system or sex-specific mortality during egg formation, egg survival (to hatching), or chick stages. Mountain Plovers did not differ from parity for the primary sex ratio, suggesting equal investment into the sexes at egg formation. A small male skew in egg survival and a more pronounced male skew in chick survival may provide possible mechanisms for the male skewed adult population. Nonetheless, our results suggest a similar production of males and females to the fledgling stage ( $<30$ day posthatch). Female biased mortality may be occurring after the fledgling stage.

Male and female Mountain Plover chicks exhibited the same pattern in $30 \mathrm{~d}$ survival and the $95 \%$ confidence intervals overlapped (Fig. 2) suggesting a possible seasonal or environmental source of mortality on all chicks. Time of hatching during the breeding season did influence chick survival. Male and female chicks both showed higher daily survival earlier in the breeding season which decreased as the breeding season progressed.

A number of environmental factors can contribute to a seasonal decline in chick survival. Prey resources, predator communities, and weather exhibit spatio-temporal variability and have been suggested to influence chick survival in shorebirds (Smith and Rotenberry 1990, Lengyel 2006, Schekkerman and Beintema 2007, Schekkerman et al. 2009). Prey abundance and biomass in a previous study were not related to Mountain Plover chick survival (Dreitz 2009). However, prey biomass can shift during the breeding season as resources change (Smith and Rotenberry 1990, Schekkerman and Beintema 2007) and may explain lower survival rates later in the season. Predation is another important driver of upland shorebird chick mortality (Schekkerman et al. 2009). Mountain Plover chicks in this study were observed to be depredated by several predator species with coinciding breeding seasons (e.g., Burrowing Owls, Athene cunicularia; Poulin et al. 2011), thus predation heightens demands for plovers to provide protection for their young. Extremely high $\left(>37^{\circ} \mathrm{C}\right)$ temperatures later in the breeding season result in higher potential for chick mortality from heat stress (Fletcher et al. 2013). These environmental factors can also vary among habitat types. Previous work showed chick survival differences among habitat types (Dreitz 2009) found in our study area, though our results indicate that habitat did not have an effect on sex-specific chick survival.

Female-biased mortality may be occurring at a later stage within this species' life cycle. Stopover locations, timing of migration, and migratory destinations can be different between males and females (Nebel et al. 2000, Bishop et al. 2004) and lead to mortality differences. Little is known about Mountain Plover migratory ecology or wintering ground locations. Differences amongst breeding populations in their migration patterns or winter locations could lead to sex-specific survival differences in adults, possibly explaining why annual survival is similar for males and females in a breeding population of Mountain Plovers in Montana (Dinsmore 2008).

Differences in detection of adults may explain the male skew observed in this breeding population. Behavior, habitat preference, and annual reproductive effort can all lead to different detectability between the sexes. Males of other shorebird species have more intense distraction behavior (Brunton 1990, Székely 1996, Paredes and Insley 2010), possibly contributing to increased detectability. Habitat structure may allow detection to vary, and one sex could select habitat with higher crypsis so they are more difficult to detect. In poor quality years, female Mountain Plovers may lay one nest that the male tends. In contrast, during high quality years, females may lay more than two nests within a breeding season such that she tends a nest and males tend each of the remaining nests. Knowledge of the paternity and maternity of eggs and young could improve our understanding of the mechanics of this unusual breeding system and assist in explaining if a skewed sex ratio is compatible with the Mountain Plover's breeding strategy.

Although a skewed sex ratio in Mountain Plovers is not fully understood, this study serves as a first step in evaluating the ontogeny of the male skewed sex ratio. Production of males and females in close to equal proportions suggests that resources are not being favorably allocated to males. Further, this suggests that the observed skew in the breeding population is not likely an evolutionarily adaptive trait for this species' unique breeding system. The breeding system, however, could be a response to the skewed sex ratio. Mountain Plovers may be capitalizing on the surplus of males by adopting a polyandrous breeding strategy.

Responses to this article can be read online at: http://www.ace-eco.org/issues/responses.php/772

\section{Acknowledgments:}

We sincerely thank the landowners in Lincoln County, Colorado, who provided access to their lands. We thank C. Archuleta, A. Bankert, E. Birtwistle, T. Dallas, Z. Glas, J. Green, A. Harrington, K. Hosek, L. Jenkins, P. Kelly, K. Kovach, B. Lutz, L. Messinger, C. Sample, N. Schwertner, L. Stinson for field assistance. Financial and logistical support was provided by Colorado Parks and Wildlife, the Lois Webster Fund of the Audubon Society of Greater Denver, University of Montana, Colorado State University, U.S. Fish and Wildlife Service, and the Colorado Chapter of The Wildlife Society. We thank anonymous reviewers for comments on earlier drafts of this manuscript. This work was conducted under University of Montana's Institutional Animal Care and Use Committee protocol No. 039-11PLECS-061311, Colorado State University No. 10-1655A and Colorado Parks and Wildlife No. 06-2009.

\section{LITERATURE CITED}

Awkerman, J. A., K. P. Huyvaert, J. Mangel, J. Alfaro Shigueto, and D.J. Anderson. 2006. Incidental and intentional catch threatens Galapágos Waved Albatross. Biological Conservation 133:483-489. http://dx.doi.org/10.1016/j.biocon.2006.07.010

Bishop, M. A., N. Warnock, and J. Y. Takekawa. 2004. Differential spring migration by male and female Western Sandpipers at interior and coastal stopover sites. Ardea 92:185-196.

Brook, B. W., M. A. Burgman, and R. Frankham. 2000. Differences and congruencies between PVA packages: the 
importance of sex ratio for predictions of extinction risk. Conservation Ecology 4:1-6.

Brunton, D. H. 1990. The effects of nesting stage, sex, and type of predator on parental defense by Killdeer (Charadrius vociferus): testing models of avian parental defense. Behavioral Ecology and Sociobiology 26:181-190. http://dx.doi.org/10.1007/ BF00172085

Burnham, K. P., and D. R. Anderson. 2002. Model selection and multi-model inference: a practical information-theoretic approach. Springer, New York, New York, USA.

Caccamise, D. F., and R. S. Hedin. 1985. An aerodynamic basis for selecting transmitter loads in birds. Wilson Bulletin 97:306-318.

Devineau, O., R. Choquet, and J.-D. Lebreton. 2006. Planning capture-recapture studies: straightfoward precision, bias, and power calculations. Wildlife Society Bulletin 34:1028-1035. http:// dx.doi.org/10.2193/0091-7648(2006)34[1028:PCSSPB]2.0.CO;2

Devineau, O., W. L. Kendall, P. F. Doherty Jr., T. M. Shenk, G. C. White, P. M. Lukacs, and K. P. Burnham. 2014. Increased flexibility for modeling telemetry and nest-survival data using the multistate framework. Journal of Wildlife Management 78:224-230. http://dx.doi.org/10.1002/jwmg.660

Dinsmore, S. J. 2001. Population biology of Mountain Plovers in southern Phillips County, Montana. Dissertation, Colorado State University, Fort Collins, Colorado, USA.

Dinsmore, S. J. 2008. Influence of drought on annual survival of the Mountain Plover in Montana. Condor 110:45-54. http://dx. doi.org/10.1525/cond.2008.110.1.45

Dinsmore, S. J., and F. L. Knopf. 2005. Differential parental care by adult Mountain Plovers, Charadrius montanus. Canadian Field-Naturalist 119:532-536.

Dinsmore, S. J., G. C. White, and F. L. Knopf. 2002. Advanced techniques for modeling avian nest survival. Ecology 83:3476-3488. http://dx.doi.org/10.1890/0012-9658(2002)083[3476: ATFMAN]2.0.CO;2

Dinsmore, S. J., M. B. Wunder, V. J. Dreitz, and F. L. Knopf. 2010. An assessment of factors affecting population growth of the Mountain Plover. Avian Conservation and Ecology 5(1): 5. [online] URL: http://www.ace-eco.org/vol5/iss1/art5/

Donald, P. F. 2007. Adult sex ratios in wild bird populations. Ibis 149:671-692. http://dx.doi.org/10.1111/j.1474-919X.2007.00724. $\mathrm{x}$

Dreitz, V. J. 2009. Parental behaviour of a precocial species: implications for juvenile survival. Journal of Applied Ecology 46:870-878. http://dx.doi.org/10.1111/j.1365-2664.2009.01658.x

Dreitz, V. J. 2010. Mortality of parental Mountain Plovers (Charadrius montanus) during the posthatching stage. Avian Conservation and Ecology 5(1): 4. [online] URL: http://www.aceeco.org/vol5/iss 1/art4/

Dreitz, V. J., L. A. Baeten, T. Davis, and M. M. Riordan. 2011. Testing radiotransmitter attachment techniques on Northern Bobwhite and Chukar Chicks. Wildlife Society Bulletin 35:475-480. http://dx.doi.org/10.1002/wsb.73
Dreitz, V. J., M. B. Wunder, and F. L. Knopf. 2005. Movements and home ranges of Mountain Plovers raising broods in three Colorado landscapes. Wilson Bulletin 117:128-132. http://dx.doi. org/10.1676/03-116

Fair, J., E. Paul, and J. Jones, editors. 2010. Guidelines to the use of wild birds in research. Ornithological Council, Washington, D. C., USA.

Fletcher, K., D. Howarth, A. Kirby, R. Dunn, and A. Smith. 2013. Effect of climate change on breeding phenology, clutch size and chick survival of an upland bird. Ibis 155:456-463. http://dx.doi. org/10.1111/ibi.12055

Graul, W. D. 1975. Breeding biology of Mountain Plover. Wilson Bulletin 87:6-31.

Hardy, I. C. W. 2002. Sex ratios: concepts and research methods. Cambridge University Press, Cambridge, UK. http://dx.doi. org/10.1017/cbo9780511542053

Hosmer, D. W., and S. Lemeshow. 2000. Applied logistic regression. Second edition. Wiley-Interscience, New York, New York, USA. http://dx.doi.org/10.1002/0471722146

Knopf, F. L., and J. R. Rupert. 1996. Reproduction and movements of Mountain Plovers breeding in Colorado. Wilson Bulletin 108:28-35.

Knopf, F. L., and M. B. Wunder. 2006. Mountain Plover (Charadrius montanus). In A. Poole and F. Gill, editors. Birds of North America. Academy of Natural Sciences, Philadelphia, Pennsylvania and American Ornithologists' Union, Washington, D.C., USA.

Kokko, H., and M. D. Jennions. 2008. Parental investment, sexual selection and sex ratios. Journal of Evolutionary Biology 21:919-948. http://dx.doi.org/10.1111/j.1420-9101.2008.01540.x

Kosztolányi, A., Z. Barta, C. Küpper, and T. Székely. 2011. Persistence of an extreme male-biased adult sex ratio in a natural population of polyandrous bird. Journal of Evolutionary Biology 24:1842-1846. http://dx.doi.org/10.1111/j.1420-9101.2011.02305. $\mathrm{x}$

Krackow, S., and E. Tkadlec. 2001. Analysis of brood sex ratios: implications of offspring clustering. Behavioral Ecology and Sociobiology 50:293-301. http://dx.doi.org/10.1007/s002650100366

Lengyel, S. 2006. Spatial differences in breeding success in the Pied Avocet Recurvirostra avosetta: effects of habitat on hatching success and chick survival. Journal of Avian Biology 37:381-395. http://dx.doi.org/10.1111/j.0908-8857.2006.03501.x

Leshyk, R., E. Nol, D. M. Burke, G. Burness. 2012. Logging affects fledgling sex ratios and baseline corticosterone in a forest songbird. PLoS ONE 7(3):e33124. http://dx.doi.org/10.1371/ journal.pone.0033124

Lukacs, P. M., V. J. Dreitz, F. L. Knopf, and K. P. Burnham. 2004. Estimating survival probabilities of unmarked dependent young when detection is imperfect. Condor 106:926-931. http://dx.doi. org/10.1650/7583

McNamara, J. M., T. Székely, J. N. Webb, and A. I. Hvouston. 2000. A dynamic game-theoretic model of parental care. Journal of Theoretical Biology 205:605-623. http://dx.doi.org/10.1006/ jtbi.2000.2093 
Nebel, S., T. Piersma, J. A. Van Gils, A. Dekinga, and B. Spaans. 2000. Length of stopover, fuel storage and a sex-bias in the occurrence of red knots Calidris c. canutus and C-c. islandica in the Wadden Sea during southward migration. Ardea 88:165-176.

Nichols, J. D., J. R. Sauer, K. H. Pollock, and J. B. Hestbeck. 1992. Estimating transition probabilities for stage-based population projection matrices using capture-recapture data. Ecology 73:306-312. http://dx.doi.org/10.2307/1938741

Nol, E., M. S. Blanken, and L. Flynn. 1997. Sources of variation in clutch size, egg size and clutch completion dates of Semipalmated Plovers in Churchill, Manitoba. Condor 99:389-396. http://dx.doi.org/10.2307/1369945

Paredes, R., and S. J. Insley. 2010. Sex-biased aggression and maleonly care at sea in Brünnich's Guillemots Uria lomvia and Razorbills Alca torda. Ibis 152:48-62. http://dx.doi.org/10.1111/ j.1474-919X.2009.00973.X

Poulin, R., L. D. Todd, E. A. Haug, B. A. Millsap and M. S. Martell. 2011. Burrowing Owl (Athene cunicularia). In A. Poole, editor. The birds of North America online. Cornell Lab of Ornithology, Ithaca, New York, USA.

R Core Team. 2013. R: A language and environment for statistical computing. R Foundation for Statistical Computing, Vienna, Austria. ISBN 3-900051-07-0. [online] URL: http://www.Rproject.org/

Rappole, J. H., and A. R. Tipton. 1991. New harness design for attachment of radio transmitters to small passerines. Journal of Field Ornithology 62:335-337.

Reynolds, J. D., and T. Székely. 1997. The evolution of parental care in shorebirds: life histories, ecology, and sexual selection. Behavioral Ecology 8:126-134. http://dx.doi.org/10.1093/beheco/8.2.126

Rickenbach, O., M. U. Grüebler, M. Schaub, A. Koller, B. NaefDaenzer, and L. Schifferli. 2011. Exclusion of ground predators improves Northern Lapwing Vanellus vanellus chick survival. Ibis 153:531-542. http://dx.doi.org/10.1111/j.1474-919X.2011.01136. $\mathrm{x}$

Sauer, J. R., J. E. Hines, J. E. Fallon, K. L. Pardieck, D. J. Ziolkowski Jr., and W. A. Link. 2011. The North American breeding bird survey, results and analysis 1966 - 2010. Version 12.07.2011. U.S. Geological Survey Patuxent Wildlife Research Center, Laurel, Maryland, USA.

Schekkerman, H., and A. J. Beintema. 2007. Abundance of invertebrates and foraging success of Black-tailed Godwit Limosa limosa chicks in relation to agricultural grassland management. Ardea 95:39-54. http://dx.doi.org/10.5253/078.095.0105

Schekkerman, H., W. Teunissen, and E. Oosterveld. 2009. Mortality of Black-Tailed Godwit Limosa limosa and Northern Lapwing Vanellus vanellus chicks in wet grasslands: influence of predation and agriculture. Journal of Ornithology 150:133-145. http://dx.doi.org/10.1007/s10336-008-0328-4

Skrade, P. D. B., and S. J. Dinsmore. 2013. Egg-size investment in a bird with uniparental incubation by both sexes. Condor 115:508-514. http://dx.doi.org/10.1525/cond.2013.120014

Smith, K. G., and J. T. Rotenberry. 1990. Quantifying food resources in avian studies: present problems and future needs. Studies in Avian Biology 13:3-5.

Székely, T. 1996. Brood desertion in Kentish Plover Charadrius alexandrinus: an experimental test of parental quality and remating opportunities. Ibis 138:749-755. http://dx.doi. org/10.1111/j.1474-919X.1996.tb08832.X

Székely, T., I. C. Cuthill, S. Yezerinac, R. Griffiths, and J. Kis. 2004. Brood sex ratio in the Kentish Plover. Behavioral Ecology 15:58-62. http://dx.doi.org/10.1093/beheco/arg105

Székely, T., G. H. Thomas, and I. C. Cuthill. 2006. Sexual conflict, ecology, and breeding systems in shorebirds. BioScience 56:801-808. http://dx.doi.org/10.1641/0006-3568(2006)56[801:SCEABS] 2.0. $\mathrm{CO} ; 2$

Thomas, G. H., T. Székely, and J. D. Reynolds. 2007. Sexual conflict and the evolution of breeding systems in shorebirds. Advances in the Study of Behavior 37:279-342. http://dx.doi. org/10.1016/S0065-3454(07)37006-X

U.S. Fish and Wildlife Service (USFWS). 2011. Endangered and threatened wildlife and plants; withdrawal of the proposed rule to list the Mountain Plover as threatened. Federal Register 76:27756-27799.

Westerskov, K. 1950. Methods for determining the age of game bird eggs. Journal of Wildlife Management 14:56-67. http://dx.doi. org/10.2307/3795978

White, G. C., and K. P. Burnham. 1999. Program MARK: survival estimation from populations of marked animals. Bird Study 46: S120-S139. http://dx.doi.org/10.1080/00063659909477239

White, G. C., W. L. Kendall, and R. J. Barker. 2006. Multistate survival models and their extensions in Program MARK. Journal of Wildlife Management 70:1521-1529. http://dx.doi. org/10.2193/0022-541X(2006)70[1521:MSMATE]2.0.CO;2
Editor-in-Chief: Ryan Norris Subject Editor: Arie J.van Noordwijk
Sponsored by the Society of Canadian Ornithologists and Bird Studies Canada Parrainée par la Société des ornithologistes du Canada et Études d'oiseaux Canada

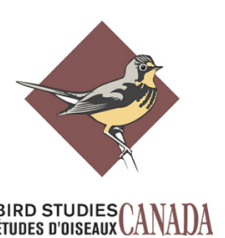

